\title{
IMPERATA CYLINDRICA (LINN.) RAEUSCH IN THE GRASSLANDS OF PABITORA WILDLIFE SANCTUARY, ASSAM, INDIA
}

\author{
Arati Bairagee and Jatin Kalita
}

Dolphin Conservation Society, Blue Hill, Jyotinagar, Guwahati, Assam 21, India.

Email: arati_bairagee@rediffmail.com

\begin{abstract}
A randomized -block experiment was carried out in Pabitora Wildlife Sanctuary to study the ecology and the growth of Imperata cylindrica in both managed and non-managed areas. I. cylindrica increased in abundance in disturbed/managed plots and declined in abundance in unmanaged plots. I. cylindrica is a shade-intolerant grass species and therefore a build up of litter and increased shading on the unmanaged plots may result in a decline in its abundance and an increase in the abundance of shade-tolerant grasses. After cutting, burning or grazing, I. cylindrica is the first species to resprout and grow dominantly over other species.
\end{abstract}

KeYwords

Erianthus ravanae, grassland, Imperata cylindrica, Pabitora Wildlife Sanctuary, Saccharum spontaneum, wildlife

Pabitora Wildlife Sanctuary in Assam is one of the remaining examples of a tropical grassland in India. The Sanctuary $\left(26^{\circ} 12^{\prime}-\right.$ $26^{0} 15^{\prime} \mathrm{N} \& 90^{\circ} 2^{\prime}-90^{0} 5^{\prime} \mathrm{E}$ ) occupies a total area of $38.81 \mathrm{~km}^{2}$ in the Valley of Kallong, a small southern tributary of river Brahmaputra. The Sanctuary is nourishing a considerably large area of healthy tropical alluvial grassland which can also be referred as Imperata grassland. A total of $72.25 \%$ area of the Sanctuary is covered by this type of grassland having Imperata cylindrica as the major and, dominant species with Phragmites karka and Saccharum spontaneum as the associated species. The trees cover almost $13.09 \%$ of the total area out of which Albizzia procera covers $90 \%$ of the tree forest as a result of secondary succession.

This important grassland supports a wide range of biodiversity and is a subsistence resource for the local community in the form of cane and thatch for house building. It appears from the grassland utilization that Imperata cylindrica is an economically important species which has a good market demand and therefore value. This Sanctuary is famous for the Indian Onehorned Rhinoceros bearing Asia's highest density. Other animals like Leopard, Wild Buffalo, Wild Boar, Civet Cat, Fishing Cat, Python and Cobra are also present.

The climate of the study is monsoonal with average annual rainfall of about $3000 \mathrm{~mm}$. A cool dry season lasts from October to February, followed by a hot dry season until April-May with an average maximum temperature of $38^{\circ} \mathrm{C}$ and minimum of $9^{\circ} \mathrm{C}$.

Practically, there is very little or no management of the grassland in this region. The only management policy practiced in the Pabitora Sanctuary is burning which is also not directly aimed to managed the grassland and its animals. The main reason of annual burning of the grassland in this region is to improve the visibility inside the Sanctuary. Burning is generally not controlled, and planned. The effects of the burning is neither recorded nor studied. Moreover, the whole area is surrounded by 22 revenue villages and these villages utilize the grassland of the Sanctuary as the major source of thatch for house building.

Imperata cylindrica is one of the primary food sources of rhinos. The present studies was made to emphasise this fact and understand important limiting factor constraints for the species. 1. To study the present status of $I$. cylindrica dominated grassland in the Sanctuary.

2. To identify other different dominant grass species and their distribution pattern in the Sanctuary.

3. To study associations between animal species and grass type assemblages.

4. To study the present practice of grassland management.

\section{Methods}

Randomized blocks: During the survey, Pabitora Wildlife Sanctuary was divided into 25 blocks and designated under some camps. These camps were Noltoli, Kachuoni, Khulabhuyan, Pokari Dipirang, Hahsora, Tuplung, Kamalpur, Buramayang, Bordia and Nekera. The blocks were of $35 \times 35 \mathrm{~m}$ size inside which, small quadrats of $5 \mathrm{x} 5 \mathrm{~m}$ were taken randomly. This method is also called randomized block design method.

Data were collected from each quadrat and the dominant grass species were identified in the Department of Botany, Gauhati University. Shrubs, trees or tall grass species occurring in a plot, but not falling within sampling quadrats, were also recorded. Visual estimates of the percentage of the dominant grass species were also made in the study plots.

In each plot, indirect and direct monitoring methods were used to measure animal utilization. Signs of mainly pellets and footprints were studied. Unidentified pellets were collected and identified in the Department of Zoology, Gauhati University. Plots were surveyed during cool, dry season (October-January) before the grasslands dried and were burned. The period of study was October 1999 to March 2001.

Species preference for different grassland assemblages were calculated using Jacobs Index (Jacobs, 1974):

$$
\mathrm{D}=\frac{\underline{\mathrm{r}-\mathrm{p}}}{\mathrm{r}+\mathrm{p}}-2 \mathrm{rp}
$$

where, $\mathrm{r}$ is the proportion of $5 \mathrm{x} 5 \mathrm{~m}$ quadrats in which a species was present in a given plant assemblage and $\mathrm{p}$ is the proportion of total number of $5 \times 5 \mathrm{~m}$ quadrats consisting of a given plant 
Table 1. Grass species in all study blocks

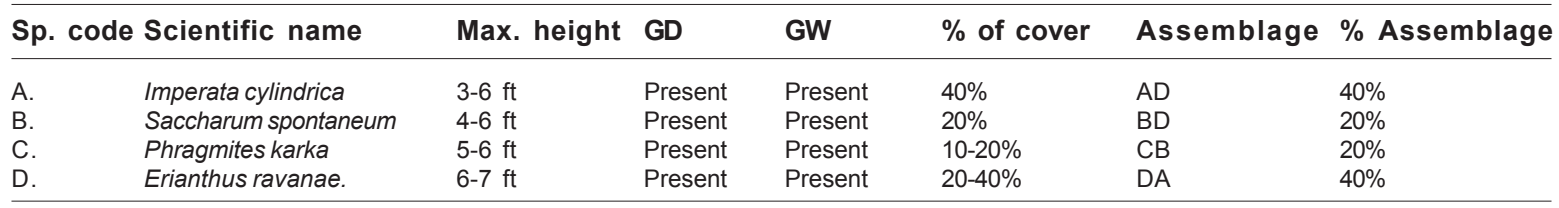

GD - grazing by domesticated animals; GW - grazing by wild animals

assemblage. $\mathrm{D}$ varies between +1 for complete selection of a plant assemblage and -1 for complete avoidance of a plant assemblage.

$\mathrm{r}$ (Mean relative abundance $)=$

No. of quadrats in which a species present in a plant assemblage Total no. of quadrates in a plant assemblage

(Muller-Dombois \& Ellenberg, 1974; Lehmkuhl 1994; Peet et al., 1997).

\section{Results AND Discussion}

Four major grass species occur predominantly in the study site which cover almost $90 \%$ of the total grassland area. They are Imperata cylindrica, Saccharum spontaneum, Erianthus ravanae and Phragmites karka. Other grass species are Arundo donax, Pollinia ciliata and Cynodon dactylon.

Table 1 shows the high percentage of I. cylindrica in the study blocks. Except in the wet areas, I. cylindrica which is the shortest of all tall grass species is present in all study blocks. Grazing is more or less common in all the study areas. Of the seven tall grass species recorded, four contributed over $90 \%$ of the total cover of grasses. Out of the four dominant species, I. cylindrica was found to be structurally important in all experimental blocks.

In the study area, it was observed that I. cylindrica shoots resprout generally in three to seven days after burning. The mean shoot height of I. cylindrica is $.9-1.7 \mathrm{~m}$ during the full growth period. The shoots are visible usually after three to four days of burning.

In Pabitora, the management pattern is not always strategic. It appears that management does not involve the cutting practice except for utilization by local people which is usually patchy. Management only involves controlled burning irrespective of cut or non-cut areas and hence all the areas are not burned after

Table 2. Name of the dominant grass species identified in the study

\begin{tabular}{llll}
\hline Name & Location & Grazing & $\%$ \\
\hline Imperata cylindrica & Disturbed area & Maximum & $40 \%$ \\
Saccharum spontaneum & Wet area & Maximum & $20 \%$ \\
Saccharum fuscum & Wet area & Medium & $5 \%$ \\
Phragmites karka & Watershed area & Medium & $10 \%$ \\
Erianthus ravanae & Marshy area & Maximum & $25 \%$ \\
Cynodon dactylon & Almost all areas & Maximum & - \\
Dactyloctenium aegyptium & Grassland & Minimum & - \\
Cyperus brivifolius & Marshy area & Minimum & - \\
\hline
\end{tabular}

cutting. Therefore, the mean shoot heights vary in different study blocks (Bell, 1997).

The growth of I. cylindrica is significantly dominant in disturbed and managed areas. On the contrary, in unmanaged and undisturbed areas, growth pattern of this species was observed to be slower and the assemblage pattern was dominated by other grass species along with the forbs (Figs. 1, 2 \& 3). Imperata cylindrica rapidly colonizes only disturbed sites (Brook, 1989). It has a high root ratio of rhizome and shoot which provides a source of dry matter for regeneration after cutting or burning (Saxena \& Ramakrishnan, 1983; Peet et al., 1999). It was also reported that I. cylindrica is shade-intolerant (Brook, 1989), shading reduces both shoot and rhizome biomass (Soer-jani 1970). It is therefore possible that a build up of litter and increased shading on the unmanaged plots might result in a decline in the abundance of $I$. cylindrica and an increase in the abundance of shade-tolerant grasses (Tilman \& Wedin, 1991; Peet \& Bell 1999). I. cylindrica dominated grasslands are often described as a fire climax community (Seth, 1970; Falvey, 1981; Skerman \& Reveros, 1989; Peet \& Bell, 1999) and in northern India they are considered to dominate following fire, cutting and grazing, being the first stage of degradation of Phragmites - Saccharum - Erianthus community, which is also true in the Pabitora Sanctuary.

\section{Percentage of assemblages with $I$. cylindrica}

It was observed that I. cylindrica has the following average degrees of assemblage with the other three dominant grass species in all study blocks $-I$.cylindrica $30 \%$; cylindrica + E. ravanae $35 \%$; I. cylindrica + S. spontaneum $20 \%$; I. cylindrica + P. karka $15 \%$.

Although during the study period the percentage of assemblage

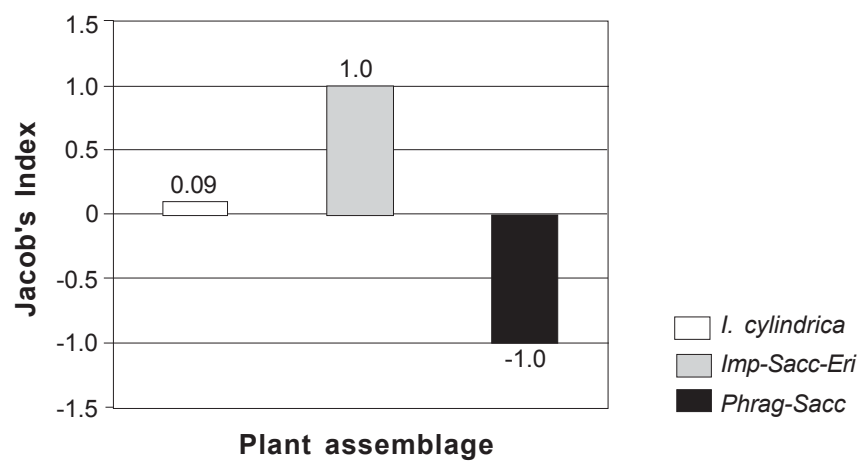

Figure 1. Species preference for different grassland assemblages - Rhino 


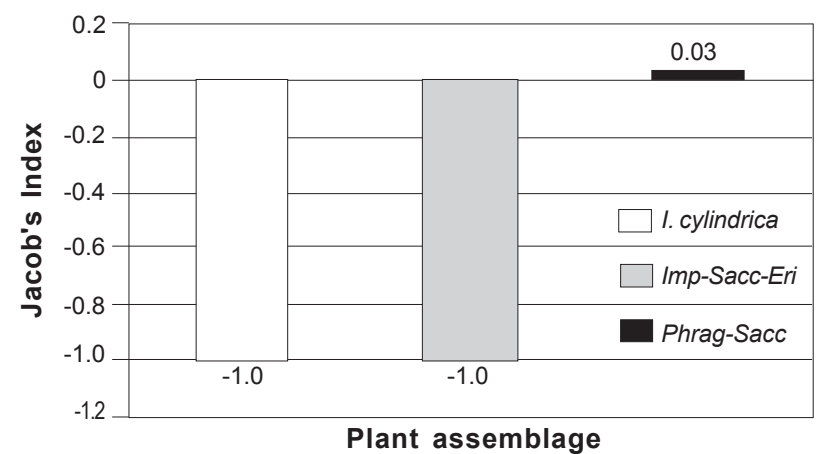

Figure 2. Species preference for different grassland assemblages - Buffalo

was found to remain the same, I. cylindrica showed a tendency to over dominate the other three species in the managed areas.

The following preferences were observed for the dwelling grassland animal species:

Species

Rhinoceros

Sus scrofa

Bubalus bubalis

Domestic cattle

Assemblages

I. cylindrica - S. spontaneum

All assemblages

P. karka - S. spontaneum

All assemblages

It has been shown that Imperata is preferred by Rhino and also Phragmites karka, Saccharum spontaneum, Cynodon dactylon and Erianthus ravanae (Bhattacharyya, 1991). Imperata cylindrica dominated grasslands of the Pabitora Wildlife Sanctuary is common in many features with savanna systems in terms of climate, seasonality and structure (Medina \& Huber, 1998). Savannas are typically dominated by grasses Poaceae, of which a few species is highly dominant.

Other grassland associated plant species

$\begin{array}{lll}\text { Cardiospermum helicacabum } & 11 . & \text { Xanthium strumarium } \\ \text { Leucas aspera } & 12 . & \text { Pouzolzia indica } \\ \text { Solanum ferox } & 13 . & \text { Eupatorium odoratum } \\ \text { Polygonum plebajum } & 14 . & \text { Enhydra fluctuans } \\ \text { Polypodium sp. } & 15 . & \text { Polygonum sp. } \\ \text { Mikania scandens } & 16 . & \text { Desmodium trifoliatum } \\ \text { Naphrodium cuculantum } & 17 . & \text { Cyclosorus extensum } \\ \text { Ipomoea aquatica } & 18 . & \text { Spelanthes paniculata } \\ \text { Polygonum barbatum } & 19 . & \text { Rosa sp. } \\ \text { Rungia parviflora } & 20 . & \text { Teraxacum sp. } \\ & 21 . & \text { Mimosa pudica }\end{array}$

\section{REFERENCES}

Bhattachryya, B.K. (1991). Ecology of Rhinoceros unicornis in Kaziranga National Park, Ph.D. Thesis.

Bell, D.J. and W.L.R. Oliver (1992). Northern Indian tall grasslands: Management and species conservation with special reference to fire. Tropical ecosystem: Ecology and Management pp.109-123.

Brook, R.M. (1989). Review of Literature on Imperata cylindrica (L.) Raeuschel with particular reference to South-east Asia. Tropical Pest Management 35: 12-25.

Brown, K. (1997). Plain tales from the grasslands: extraction, value and utilization of biomass in Royal Bardia National Park, Nepal. Biodiversity and Conservation 6: 59-74.

Falvey, J.L. (1981). Imperata cylindrica and animal production in SouthEast Asia: a review. Tropical Grasslands 15: 52-56.

Lehmkuhl, J.F. (1994). A classification of sub-tropical riverine grassland and forest in Chitwan National Park, Nepal. Vegetation 111: 29-43.

Medina, E. and O. Huber (1992). The role of biodiversity in the functioning of Savanna ecosystem. In: Solbrig, O.T., H.M.Van Emden and P.G.W.J. van Oordt (editors). Biodiversity and Global Change, pp.141160. IUBS, Paris.

Muller-Dombois, D. and Ellenberg (1974). Aims and Methods of Vegetation Ecology. Wiley, New York.

Peet, N.B., A.R. Watkinson, D.J. Bell and B.J. Kattel (1999). Plant diversity in the threatened sub-tropical grasslands of Nepal; Biological Conservation 88: 193-206.

Seth, A.K. (1970). Chemical control of Imperata cylindrica (L) Beauv. in Malayasia. Weed Research 10: 87-93.

Skerman, P.J. and F. Riveros (1989). Tropical grasses. Food and Agriculture Organisation of the United Nations, Rome.

Soerjani, M. (1970). Alang-alang Imperata cylindrica (L.) Beauv. (1812). Pattern of growth as related to its problem of control. Biotrop Bulletin, Indonesia, 1.

Saxena, K.G. and P.S. Ramakrishnan (1983). Growth and allocation strategies of some perennial weeds of slash and burn agriculture (jhum) in northeastern India. Canadian Journal of Botany 61: 1300-1306.

Tilman, D. and D. Wedin (1991). Oscillations and chaos in the dynamics of a perennial grass. Nature 353: 653-655

Wiens, J.A. (1981). Scale problems in avian censusing. Studies in Avian Biology 6: 513-21. 